\title{
ДО ПРОБЛЕМИ ДУХОВНОГО ВИХОВАННЯ СТУДЕНТІВ МЕДИЧНИХ ВУЗІВ
}

\author{
Н. В. Скрипник, П. Ф. Дудій, Н. В. Пасєчко* \\ ДВНЗ “Івано-Франківський наиіональний медичний університет”, \\ *ДВНЗ “Тернопільський державний медичний університет імені І. Я. Горбачевського МОЗ України”
}

\section{THE PROBLEM OF THE SPIRITUAL TRAINING OF STUDENTS OF MEDICAL INSTITUTES}

\author{
N. V. Skrypnyk, P. F. Dudiy, N. V. Pasyechko* \\ SHEI "Ivano-Frankivsk National Medical University", \\ *SHEI "Ternopil State Medical University by I. Ya. Horbachevsky of MPH of Ukraine”
}

\begin{abstract}
У статті обговорюються питання, пов'язані з вихованням студентів медичних навчальних закладів. Поставлена проблема набувас особливої актуальності сьогодні, у час складних соціально-економічних й політичних катаклізмів. Автори показують, що формування духовного світогляду молодої людини, яка вибрала собі найбільш відповідальну та благородну професію, потребує щоденної праці. Професійна підготовка медичного працівника повинна формуватися перш за все на загальнолюдських, християнських і етичних принципах. Духовність і медицина, як показують автори, поняття нероздільні і складають фундамент сучасної науки і практики.
\end{abstract}

The article adduces the issues concerning the training of students of medical educational institutions. Problem set in the article assumes special importance today, during the social and economic problems and the political differences. In the article the authors show that molding of the spirituality of the young person, who selected the most noble profession requires daily labor. The professional training of medical worker must be formed, first of all, on the general human, Christian and ethical principles. Spirituality and medicine, as not not divisible show the author of concept and compose the foundation of contemporary science and practice.

Вступ. Духовність і медицина... Ці два поняття не роздільні, оскільки добре усвідомлюємо, що саме на такій міцній основі має триматися медична наука i практика. Дбаючи про здоров'я тіла, піклуючись про запобігання і попередження хвороб, маємо водночас не нехтувати духом, бо визначальний чинник здоров'я - духовність. Стародавній псалмоспівець визнавав: “Очі мої підводжу я на гори: звідки прийде моя допомога? Допомога моя від Господа, що створив небо й землю" [Пс. 121 (120) 1-2].

Поставлена проблема набуває особливої актуальності сьогодні, у час складних соціально-економічних й політичних катаклізмів, які впливають особливо гостро на молодих людей. Формування духовного світу молоді в цілому i, зокрема, молоді, яка обрала для себе фах найблагороднішої і найвідповідальнішої з професій - медика - завдання масштабне, складне i, без сумніву, вимагає кропіткої наполегливої праці. Маємо розуміти, що професійна підготовка медичного працівника полягає не лише у формуванні певної системи знань, умінь та навичок, але й у розвитку таких специфічних рис особистості, що () Н. В. Скрипник, П. Ф. Дудій, Н. В. Пасєчко відповідають вимогам майбутньої діяльності [3]. Тому саме у вузі маємо продовжити орієнтацію на формування у студентства загальнолюдських духовних надбань народу, його традицій, християнських та етичних норм співжиття, які споконвічно сповідували українці.

Справедливими й на часі видаються слова ученого В. Ф. Брауна: “Лише нове звернення до Бога може врятувати світ від катастрофи, що насувається. Наука і релігія - це сестри, а не вороги". У час, коли рівень духовності катастрофічно знижується у зв'язку з відсутністю соціальної захищеності, явним чи прихованим безробіттям, невизначеністю моральних орієнтирів у політиці, розривом між морально-етичним розвитком людства і науково-технічним прогресом, зважити треба на суттєве, первинно-визначальне - Дух. Творець сказав: “Я є Світло...” Це світло передане кожному з нас, тому ми - теж Світло. Віддати його іншому - це святий обов' язок громадянина $\mathrm{i}$ людини, а втричі важливіше це тоді, коли професійна діяльність зобов' язує працювати з іншими людьми, присвячувати частину себе іншим [2]. 
Основна частина. Сьогодні, як ніколи, лежить велика відповідальність на медичних працівниках, які мають донести світло до пацієнта, лікувати не лише тіло, а бачити й розуміти внутрішній світ іншої людини, ії проблеми, суть тієї чи іншої хвороби. Зважмо на те, що людство вражене недугою моральної і духовної слабості: насильство, породжене втратою віри й спокою у душах, техногенні і екологічні катастрофи, стрімкі темпи життя, СНІД, наркоманія, руйнація власного "я" та внутрішня нестабільність [7].

Тому більшість вітчизняних та зарубіжних ученихдослідників сповідують істину: без культу духовності людство загине. У цьому переконливим фактором $є$ уроки історії, які нам треба усвідомлювати серцем і розумом, i, звичайно, повернення до вічних істин Книги Книг, де можемо черпати відповіді на питання, знайти заспокоєння, розраду та духовну поживу для себе і того, хто йде поруч з нами.

Тим більше, що ми, українці, народ віруючий. Це в наших генах. Щоправда багато втрачено у часи тоталітарні, та повернути орієнтацію вузівських програм до християнських моральних цінностей, які є основою гуманістичних ідеалів, ніколи не пізно, бо у нас $\epsilon$ в цьому плані міцні традиції, укладені впродовж історичного розвитку.

Згадаймо, що релігійність і патріотизм - головні джерела традиційного виховання української молоді від часів Київської Русі. Українська історія знає взірцеві славні імена, які посвятились цілком церкві i народові: княгиня Ольга, святий Володимир Великий, святі Борис і Гліб, а за ними цілі хори преподобних Божих угодників і мучеників. Служіння Богові й Батьківщині - дві абсолютні цінності українського народу, які були, є і будуть фундаментом цивілізованого суспільства. Дуже глибоко розумів місію педагога наш філософ Григорій Сковорода. Зовсім не завадило б нам, сьогоднішнім, заглянути до його спадщини. Як писав геніальний Г. Сковорода, людина народжується двічі: фізично й духовно. Біля духовної колиски стоїть духовний наставник-учитель, який стає другим батьком, матір'ю, бо прищеплює їі душі високі моральні якості віри, надії, любові, глибокої поваги до рідної землі, свого народу, держави. Духовну людину, на думку Г. Сковороди та інших українських мислителів, творить шлях добра: через пізнання, усвідомлення й розуміння своєї істинної духовної природи, свого призначення у світі, до чого людину закликає вчення Христа: “Бог і щастя - недалеко воно. Близько воно. У серці і душі твоїй” [6].

Вчитуючись у біографії багатьох видатних лікарів, відзначаємо, що жили вони вірою. Рудольф Вірхов і
Луї Пастер, Микола Пирогов і Феофіл Яновський, Іван Павлов і Володимир Філатов, професор Валентин Войно-Ясенецький, автор "Нарисів гнійної хірургії” (архієпископ Лука), Андрій Блум (митрополит Сурожський Антоній). Згадаймо хоча б, що видатним ученим був архієпископ св. Василій Великий [бл. 330379], який правильно пояснював зміну фаз Місяця і вказував розміри Сонця, впливом Місяця обгрунтовував припливи і відливи і навіть пояснив механізм утворення веселки заломленням сонячних променів у краплинах води. Після падіння Західної Римської імперії саме монастирі стали вогнищами культури, де переписувались і зберігались твори давніх учених (для прикладу, символ бенедиктинського монашого ордену - хрест, книга і плуг). А коли на початку другого тисячоліття н. е. в містах Свропи почали засновуватися університети, то професорами в них довгий час були виключно люди духовного стану. Серед видатних вчених папа Сильвестр II (помер у 1003 р., за переказом, він став прототипом доктора Фауста), німецький філософ Альберт Великий [бл. 1200-1280], італійський філософ Тома Аквінський і багато інших. Відомо, що це німецький математик і астроном єзуїт Христофор Сейнер (1575-1650) почав вивчати Сонце, і його книга про найближчу до нас зірку (1600$1675)$ була тоді найдетальнішою розповіддю про неї. Першу карту Місяця склав бельгійський математик єзуїт Мішель Лангрен (1600-1675). Подвійність зірок виявив у 1650 р. італійський учений єзуїт Жоан Річчолі (1598-1671). Точні виміри радіуса Землі у XVII ст. виконав французький астроном аббат Жак Пікар (1620-1682). Першу малу планету 1 січня 1801 р. відкрив італійський астроном священик Джузеппе Піацці (1746-1826) [2].

Серед учених минулого століття варто згадати, зокрема, видатного італійського вченого єзуїта Анжело Секкі (1818-1888) - автора понад 300 наукових праць 3 астрономії та астрофізики, члена усіх найважливіших європейських академій наук. До речі, сьогодні Папська академія наук є однією 3 найавторитетніших у світі. Прикладом сучасного лікаря i водночас пастиря душ є Михайло Вікторович Суховій, доктор медичних наук, настоятель храму на честь ікони Божої Матері "Пантанасса" на території 9-ї міської лікарні міста Києва.

У нашій історії найяскравішим прикладом плідного поєднання медицини з релігією може слугувати “Києво-Печерський патерик”. Більш сучасним аналогічним документом, який, спираючись на канони християнської Церкви й використовуючи останні досягнення медичної науки, викладає моральні засади 
професійної діяльності лікаря, є всесвітня Хартія працівників охорони здоров'я. У друкованій передмові до неї, зокрема, вказується, що, “виходячи із очевидності створення фундаментального постулату про недоторканість життя, сприяння життю і потребу охороняти життя як основу біоетики, Церква займає позицію, яка є конструктивною і відкритою щодо поступу науки і технологій, коли цей поступ поєднується з розвитком цивілізації”. Із цього ж таки документа варто ще було б процитувати слова Івана-Павла II, що для лікаря “"пацієнт... ніколи не є лише клінічним випадком, а завжди - хворою людиною, до якої “він має ставитись із щирою симпатією”.

“Якби ми вчились так, як треба, то й мудрість би була своя", - мовив Тарас Шевченко. Студіюючій молоді, яка обирає найгуманнішу з професій, треба розуміти значення цих слів великого сина України.

Світ знає, що на 10 Божих Заповідях тримається духовність людства. Чи придумав хтось щось краще?

Так, у тоталітарні часи друкували щороку сотні книжок, в яких твердилось: Бога немає. В усіх цих книгах говорилося про те, нібито "наука несумісна 3 релігією”, нібито “наука перебуває в стані неперервної боротьби з релігією”. Від нас приховували, що більшість найвидатніших учених світу були і $є$ глибоко віруючими і це не заважало (і не заважає) їм здійснювати важливі наукові відкриття. Якби справді релігія була несумісна з наукою, то відтоді, відколи наука існує, всі вчені мали б бути атеїстами. А це, як побачимо, зовсім не так. В 1909 р. німецький професор Др. Денерт опублікував книгу з результатами опитування 262 провідних вчених світу. 3 них 92\% визначили себе віруючими і лише $2 \%$ атеїстами, 6 зачислили себе до агностиків, тобто до таких, хто “не знає”, хто не має з цього питання певної думки. На початку 30-х років із 133 англійських та американських учених визнали себе віруючими 89 \%. Ці результати були наведені тоді ж у книжці Тамбура "Релігійні вірування сучасних учених". Найповнішу збірку висловлювань провідних учених ХХ ст. на релігійні теми "Що кажуть про Бога сучасні вчені" опублікував у Брюсселі (1960р.) ієромонах Куртуа. Додамо, що в наш час із кожних п'яти професорів у США чотири визнають себе віруючими [2].

Скажімо про це молоді, покличмо їі до усвідомлення своїх обов' язків перед іншою людиною, до аналізу власного “я”, подій, процесів задля самовдосконалення душі під Господнім благословенням та опікою. Як ніколи, актуальна сьогодні істина-постулат: “Дай мені, Боже, мудрість мого стану, щоб я усе сповняв, чого бажаєш, дай мені розуміти мої обо- в'язки, дай мені мудрість моїх обов'язків і дай мені виконати так, як треба і як належить на славу Твою $\mathrm{i}$ хосен моєї душі". Як часто сьогодні доводиться спостерігати і бачити на власні очі протилежне - бездіяльність, часом байдужість до хворого, який потребує доброго слова і поради від лікаря.

Майбутній лікар ще на студентській лаві має зрозуміти, що ближні потребують його допомоги, присутності, розуміння, любові. Хворий чекає на його сподвижницьку працю й милосердя, знання й культуру, зразкове життя і душевну підтримку. Це ті моральні і професійні обов'язки, які вищі за інтереси особисті. Це те, що мусиш, бо обрав саме такий фах. А за цим воістину мудре: не чини того, що тобі хочеться, а чини те, що повинен, щоб бути гідним Бога і слова "Людина".

У видатного письменника - лікаря А. П. Чехова $є$ дуже влучна думка про те, що всюди потрібні, як сонце, подвижники, які, “представляючи найбільш поетичний і життєрадісний елемент суспільства, розбуджують, утішають, облагороджують”. "Подані самим життям, - вважає він, - $\epsilon$ поза будь-якою ціною”. Такими сподвижниками на духовній ниві i мають стати майбутні лікарі. Народ вправі того від них вимагати, передовсім тому, що вони дають клятву і посвячуються нести відповідальність за здоров'я своїх пацієнтів впродовж усієї професійної діяльності. I підтримки у цій справі маємо просити у Спасителя. “Ora et labora”, - закликали мудрі римляни. Молімось та прощаймо на благо людини і кличмо за собою молодь.

Проміжок часу відмежовує нас від славнозвісних подій 23-24 червня 2002 р., коли українська громадськість зустрічала на рідній землі Святішого Отця Івана Павла II Папу Римського. Перші слова, що пролунали з уст Святішого Отця на Сихові під час зустрічі з молоддю: "Господи, а до кого ж іти нам? Це ж у Тебе слова життя вічного” (Ів. 6,68). Це євангельське питання стало ключовою думкою всіх промов Папи до нашої молоді. Так, Святіший Отець подав компас, щоб допоміг у бурхливому морі життя. I ним є віра, духовність, добротворення. Віриться, що й на царині медицини будуть такі сподвижники, які основний постулат медичної етики “Не зашкодь" - цю давню Гіппократову заповідь - доповнять новим актуальним принципом: “Твори благо іншому" [5].

"Християнське виховання є більшим добром, ніж усі добра світу”, - писав митрополит Андрей Шептицький. Розуміючи вагомість цих слів мислителя, повертаємось у роботі до подальшої гуманізації ме- 
дицини, суттєвого підвищення морально-духовного рівня майбутніх лікарів [1].

У концепції виховання молоді в національній системі освіти України підкреслюється, що “ідеалом виховання на сучасному етапі є високоосвічена, професійно компетентна, всебічно розвинена особистість, наділена глибокою національною й державницькою відповідальністю - творчим, тілесним, духовно-моральним здоров'ям й естетичними, родинними й патріотичними почуттями...” [4]. А здо-

\section{Література}

1. Заборовський Я. Ю. Митрополит Андрей Шептицький / Я. Ю. Заборовський. - Львів : Видавництво “Олір”, 1995. $-176 \mathrm{c}$.

2. Климишин I. А. Вчені знаходять Бога / І. А. Климишин. - Івано-Франківськ : Нова Зоря, 1999. - 96 с.

3. Мілерян В. С. Методичні основи підготовки і проведення навчальнихзанять в медичних вузах (методичний посібник) / В. С. Мілерян. -Київ : Хрещатик, 2003. - 80 с.

4. Педагогіка вищої школи : навч. посіб. / [3. Н. Курлянд, Р. І. Хмелюк, А. В. Семенова та ін.]; за ред. 3. Н. Курлянд. - ров’я нації - скарб, який слід плекати, передавати 3 покоління у покоління, виховуючи себе, рідних й оточуючих у національній гордості, вірі в Бога та у прагненні до висот Духа.

Висновок. Отже, формування духовної культури особистості є одним 3 найважливіших завдань вищої школи.

А справжнє мислення професіонала-медика не усвідомлюється без розуміння духовних істин, відродження нації, гуманістичних цінностей.

[3-тє вид., перероб. і доп.]. - К. : Знання, 2007. - 495 с.

5. Свіщук Я. Ідіть і навчайте всі народи : проповіді / Я. Свіщук. - Львів : Свічадо, 2002. -340 с.

6. Сковорода Г. Твори : у 12 томах / Г. Сковорода. - Т. 1.К., 1994.

7. Якібчук М. В. Напрями розвитку гуманізації і комунікаційна компетентність у контексті безперервної освіти / М. В. Якібчук // Наук. часопис Національного педагогічного університету ім. М. П. Драгоманова. Серія 7 : Релігієзнавство. Культурологія. Філософія. - 11 (21). -Київ, 2007. - 153 с. 